\title{
Violências contra os Axés
}

Gerson Machado ${ }^{1}$

\section{RESUMO}

Este artigo apresenta reflexões sobre o intenso processo de intolerância religiosa enfrentado pelas religiões afro-brasileiras. Sobretudo, além do histórico de alguns acontecimentos que evidentemente demonstram esta lamentável situação, apontamos alternativas para a consolidação de estratégias de enfrentamento, através do reconhecimento da situação de violência e do estabelecimento de laços que unem as vítimas diretas em ações de positivação e visibilidade do grupo.

\section{PALAVRAS-CHAVE}

História das Religiões; religiões afro-brasileiras; violência.

\begin{abstract}
This article presents reflections about intense process of religious intolerance faced by African-brazilian religions. Above all, beyond the history of some events that clearly demonstrate this unfortunate situation, we point out alternatives to the consolidation of coping strategies, by recognizing the situation of violence and the establishment of links between the direct victims in positivation actions and group visibility.
\end{abstract}

1 Doutor em História pela UFSC (2012), Educador do Museu Arqueológico de Sambaqui de Joinville e professor da Universidade da Região de Joinville. Contato: gerson_machado@uol.com.br. 


\section{KEYWORDS}

History of Religions; afro-brazilian religions; violence

\section{Casos de violência}

A escrita de um texto que visa discutir as ações de violência das quais as religiões de matriz afro-brasileiras são vítimas requer alguns posicionamentos para que o mesmo não se configure numa ação militante, - reconhecendo, é claro, todo o potencial e pertinência desse tipo de atitude - nem em um texto meramente acadêmico-estatístico, - reconhecendo igualmente o tratamento e a apresentação deste tipo de abordagem. A aposta é a partir de alguns relatos de casos de violência, percebermos quais as estratégias utilizadas pelos grupos para o enfrentamento de tais realidades. Para este texto adoto o entendimento de que a violência pode se manifestar de diversas formas, sendo alguns casos de caráter exclusivamente psicológico, outros envolvem ações de intervenção física as quais se apresentam num gradiente que varia desde ações de negação do direito da pessoa ou grupo em externar os sinais distintivos de sua identidade religiosa, até ações criminosas que implicam em agressões que atentem contra o físico e o patrimônio de pessoas e grupos.

Diante disso gostaria de trazer à lembrança o caso de um estudante da rede municipal de educação do Rio de Janeiro que, em 25 de agosto de 2014, foi impedido de entrar na escola em que estudava por usar os fios de conta relacionados ao seu processo de iniciação no Candomblé. Este caso ganhou diversos espaços na mídia e provocou reflexões e manifestações em diversas localidades do país. Numa das reportagens ocorre o relato de que: "Segundo sua família, o menino já era vítima de preconceito há algum tempo - ele decidiu adotar a religião há cerca de dois meses. Há um mês, a diretora já impedia a entrada do aluno na escola conforme relato da mãe. Após o acontecido, ele trocou de escola"².

2 MAZZI, Carolina, $\boldsymbol{R} \boldsymbol{J}$ : Aluno é impedido de frequentar escola com guias de candomblé. Disponível em: http://educacao.uol.com.br/noticias/2014/09/03/rj-aluno-e-impedido-de-frequentar-escola-com-guias-de-candomble.htm. Acesso em 12.11.2015. 
Esse caso é emblemático, pois envolveu autoridades do alto escalão do executivo municipal, sendo que o próprio prefeito, Eduardo Paes, num encontro com o aluno e sua família, fez um pedido formal de desculpas ${ }^{3}$. Ressalta-se que a rede municipal do Rio de Janeiro, desde 2011, tem aulas de religião como parte do currículo. Todavia, neste caso específico podemos questionar o tipo de abordagem feita por esta unidade escolar, assim como a seleção de conteúdo e enfoque dado às questões das manifestações religiosas de grupo minoritário de nossa sociedade, num claro atentado ao direito à memória e à existência. Neste caso a perspectiva da escola como espaço de construção do respeito à alteridade fica completamente comprometido. Este quadro ganha contornos mais nítidos se levarmos em conta a manifestação de Silvany Eclênio, da Secretaria de Políticas de Promoção da Igualdade Racial, que afirma que "o caso envolve além de discriminação religiosa a discriminação racial"4. Nesta mesma reportagem é citada a professora Stela Guedes Caputo da Faculdade de Educação da UERJ que afirma:

... o ensino religioso no Estado e na cidade do Rio funciona como um catequizador que só aceita as religiões cristãs. E o ensino da cultura africana ainda é muito fraco, quase nulo. Além disso, temos uma bancada fundamentalista que defende apenas a sua religião, ao invés de defender os interesses de todos ${ }^{5}$.

Indubitavelmente, o ocorrido e a repercussão que ganhou nos meios de comunicação serviram para dar visibilidade à causa do combate à intolerância, discriminação e violência de cunho religioso e racial. Isto revela, sobretudo, o potencial educativo que esses meios possuem para auxiliar a conquista do direito fundamental à existência dessa parcela da população brasileira.

Um outro caso que gostaria de relembrar ocorreu em um terreiro de Olinda, em Pernambuco, em 18 de julho de 2012, e ganhou as páginas do Jornal do Comércio com a seguinte chamada: "Evangélicos tentam

${ }^{3}$ MAZZI, 2014. Acesso em 12.11.2015.

${ }^{4}$ MAZZI, 2014. Acesso em 12.11.2015.

${ }^{5}$ MAZZI, 2014. Acesso em 12.11.2015. 
invadir terreiro em Olinda" ${ }^{\text {. A }}$ A reportagem relata outro caso de intolerância religiosa:

Centenas de evangélicos com faixas e gritando palavras de ordem realizam protesto em frente a um terreiro de matriz africana e afro-brasileira - candomblé, umbanda e jurema. As imagens poderiam ser de um filme sobre a Idade Média. No entanto, foram registradas no domingo, no Varadouro, em Olinda, Grande Recife. As cenas de intolerância religiosa circularam ontem nas redes sociais e provocaram a revolta de milhares de internautas. ${ }^{7}$

Tal ocorrência serviu para mobilizar diversas comunidades de terreiros de Olinda que reunidos manifestaram repúdio ao ocorrido e decidiram registrar um boletim de ocorrência coletivo para que o caso fosse tratado como crime contra a coletividade. ${ }^{8}$ Entretanto, tal ocorrência estaria relacionada com outro fato ocorrido distante dali, no agreste pernambucano, onde, segundo a reportagem, uma semana antes, “... pessoas invadiram terreiros em Brejo da Madre de Deus, (...) após o assassinato de uma criança, segundo a polícia, a mando de um pai de santo" . A reportagem tenta esclarecer, que "Pesquisadores dizem que essas religiões não realizam sacrifício de humanos"10. Apesar do destaque e da repercussão que tal reportagem dá aos fatos e à mobilização deste coletivo, o que causa espanto é o artifício narrativo do texto jornalístico que se apoiou na "fala autorizada" dos "pesquisadores" para que tal afirmação tenha sentido de verdade, num claro desprestígio dos que professam tal religião.

Um terceiro fato de violência ocorreu mais recentemente, no Sul do Brasil, no Município de Araquari, no Norte de Santa Catarina. Este ocorreu em 10 de outubro de 2015 e ganhou, como os outros casos, bastante repercussão nos meios de comunicação. A reportagem do Jornal A Notícia, informa que: "Pai de santo é agredido com pedradas em Araquari,

${ }^{6}$ Evangélicos tentam invadir terreiro em Olinda. Disponível em: http://jconline.ne10. uol.com.br/canal/cidades/noticia/2012/07/18/evan. php. Acesso em 12.11.2015.

7 Evangélicos tentam invadir terreiro em Olinda, 2012. Acesso em 12.11.2015.

8 Evangélicos tentam invadir terreiro em Olinda, 2012. Acesso em 12.11.2015.

9 Evangélicos tentam invadir terreiro em Olinda, 2012. Acesso em 12.11.2015.

${ }^{10}$ Evangélicos tentam invadir terreiro em Olinda, 2012. Acesso em 12.11.2015. 
Norte de Santa Catarina". ${ }^{11}$ Trata-se do pai de santo Israel Jesus Borges, de 54 anos, que foi agredido a pedradas no portão do terreiro que ele e a mulher dirigem no bairro Santa Mônica. A reportagem fez o seguinte relato:

De acordo com a família, vizinhos foram até o local na tarde do último sábado para reclamar do barulho e ocorreu uma discussão na qual Israel e a mulher teriam sido ameaços. As mesmas pessoas teriam retornado ao terreiro na manhã deste domingo (...)

- Acertaram uma pedra na testa dele, derrubaram o portão de casa e ficaram gritando "macumbeiro" - diz a mulher. ${ }^{12}$

Poderíamos recuperar inúmeros relatos, porém, não é caso. A pretensão é a de ilustrar um pouco essa violência endêmica que atinge diversas manifestações religiosas e mais diretamente as afro-brasileiras. Para tanto, gostaria de ajustar o foco de nossa discussão para a região Norte de Santa Catarina, a qual apresenta indícios claros desse processo, bem como, ações de combate à violência e de afirmação identitária. $\mathrm{O}$ caso relatado acima se deu numa região de conturbação entre os municípios de Araquari e o de Joinville, que é a cidade mais populosa do estado.

Sendo Joinville uma cidade profundamente marcada pelo ethos do trabalho e pelo mito do empreendedorismo alemão, a presença religiosa afro-brasileira neste cenário se apresenta de forma problemática, tendo em vista o reconhecimento e o auto- reconhecimento dos seus membros. Apesar de parecer anacrônico, na atualidade, as religiões afro-brasileiras encontram sérias dificuldades para se manifestarem em Joinville, Santa Catarina $^{13}$.

${ }^{11}$ JUNGES, Leandro S. Pai de santo é agredido com pedradas em Araquari, Norte de Santa Catarina.

Disponível em: http://anoticia.clicrbs.com.br/sc/geral/noticia/2015/10/pai-de-santo-e-agredido-com-pedradas-em-araquari-norte-de-santa-catarina-4875162.html. Acesso em 12.11.2015

12 JUNGES, 2015. Acesso em 12.11.2015.

${ }^{13}$ Situações conflituosas entre práticas religiosas afro-brasileiras e a ordem estabelecida eram muito comuns, por exemplo, durante o período colonial brasileiro, onde o estado tinha a religião católica como oficial. Nesse sentido é interessante citar o estudo de REIS (1989 e 2006) sobre as lideranças religiosas e os conflitos em decorrência do estabelecimento de espaços destinado ao culto dos orixás, voduns e inquiçes, na Bahia do século XIX. 
As expressões de alguns dos sinais diacríticos que identificam essas religiões enfrentam, além do preconceito advindo de uma considerável parcela da população - muito vinculada às religiões cristãs conhecidas pelo sistemático combate a esses sinais-, o próprio poder público que acaba interferindo nos espaços religiosos, principalmente em função das leis ambientais, que normatizam e disciplinam o volume e a intensidade dos sons produzidos pelos atabaques, a sacralização de animais, entre outros aspectos. Há relatos de que diversos terreiros foram autuados e multados, em função da inspeção feita por fiscais ligados à fundação de meio ambiente do município que, portando equipamentos medidores de decibéis, verificaram a irregularidade da manifestação sonora desses instrumentos rituais.

\title{
O culto aos Orixás e o discurso ambientalista
}

\author{
Kosiewè, kosiOrișa! ${ }^{14}$ \\ (provérbio yorubano)
}

Cristiana Tramonte ${ }^{15}$ apresenta vários dilemas enfrentados, atualmente, pela rede do povo-de-santo na região da grande Florianópolis. Para ela o grupo é continuamente demandado a se posicionar frente às questões apresentadas, como: mercantilização e caridade, optando pela última e rechaçando a primeira, visto que esta descaracteriza, profundamente, os princípios da religião e seus dogmas. Diante do dilema, ostentação e humildade, a autora afirma que o povo-de-santo busca fazer prevalecer a segunda, já que riqueza e religião são incompatíveis.

O posicionamento exigido entre devoção e profanação, segue um princípio consonante aos demais, ou seja, a opção é pela primeira qualidade, já que o ato de profanar implicaria numa queda do padrão moral dos adeptos, permitindo o desregramento e a degradação dos valores. Diante da questão posta entre a tradição e a modernidade a resposta

\footnotetext{
14 Traduzindo o provérbio: Sem folha, sem Orixá!

15 TRAMONTE, Cristiana. Com a bandeira de Oxalá! Trajetória, práticas e concepções das religiões afro-brasileiras na Grande Florianópolis. Itajaí: UNIVALI, 2001, p. 485-488.
} 
ganha um tom mais conciliador entre ambas, procurando intercambiar suas práticas e experiências com a sociedade como um todo, problematizando, inclusive, algumas práticas rituais como o sacrifício animal e os despachos sem, contudo, homogeneizá-las, valendo-se do diálogo como ferramenta de atuação frente ao dilema exposto.

Por fim a autora apresenta o dilema da relação do povo-de-santo e sua relação com a natureza como uma problemática imperiosa de se resolver, tendo em vista que "como parte da população desprivilegiada socialmente, o povo-de-santo integra a parcela diretamente atingida pelos desiquilíbrios ambientais e consequente escassez de recursos, que geram o desaparecimento de indispensáveis elementos rituais, ameaçando a tradição e causando perdas espirituais." " Sobretudo, destaca o papel central que o discurso ecológico cumpre na espiritualidade afro-brasileira, afirmando que: "a religião é responsável por estruturar a visão dos adeptos e, em alguns casos, resulta em iniciativas no cotidiano ritual e material que visam à maior preservação" ${ }^{17}$.

Disso decorre a função política e pedagógica que essas religiões cumprem na organização da vida e dos valores éticos, pois as falências dos elementos naturais resultariam numa consequente falência religiosa e espiritual. Portanto, a atuação do povo-de-santo na capital catarinense está colada a um projeto que defende uma interpelação mais harmoniosa da sociedade com os ecossistemas com os quais interagem.

Inspirado pela reflexão acima procurei entender como o coletivo do povo-de-santo, da "Manchester Catarinense"18, se articula frente às questões supracitadas, especialmente, diante do discurso ambientalista que, como sabemos, é extremante polissêmico. Desta forma, tomarei como primeiro indício uma reportagem do jornal A Notícia, publicada no ano de 2008. Neste ano, o jornal produziu uma série de reportagens denominadas "Joinville de Zarcão"19. Essas enfocavam os vários bairros da cidade, seu histórico, curiosidades e problemas.

16 TRAMONTE, 2001, p. 487.

${ }^{17}$ TRAMONTE, 2001, p. 487-488.

${ }^{18}$ Este é um dos epítetos pelos quais a cidade de Joinville é conhecida. No caso, a referência se faz em virtude do parque industrial, implantado no seu território, se constituir no maior do Estado de Santa Catarina.

${ }^{19} \mathrm{O}$ termo zarcão em Joinville significa o mesmo que ônibus urbano. 
Nesta reportagem, Jefferson Saavedra relata a situação de uma queda da água conhecida como Ronco d'Água que vinha sendo denominada de "curva da macumba", situada no Bairro Itinga, o bairro mais ao Sul da cidade, limítrofe ao município de Araquari/SC. O enfoque da reportagem foi sobre o intenso processo de degradação ambiental provocado pelo uso intensivo do local, pelo povo-de-santo da cidade, para práticas rituais como ebós, despachos, sacrifícios animais, entre outros. Vale ressaltar que o repórter apresenta sua versão baseando-se, exclusivamente, nos relatos colhidos com um morador evangélico da localidade. ${ }^{20}$

Joinville encontra-se numa região muito privilegiada em relação a presença de rios e cachoeiras que são, cada vez mais, utilizadas pelo povo-de-santo. Todavia, tais usos, por vezes, são enquadrados no discurso ambientalista como maus exemplos em termos da preservação ambiental.

Essa manifestação ostensiva, de alguns setores da sociedade, em relação às práticas ritualísticas afro-brasileiras, em especial o Candomblé, acabou distorcendo os princípios da religião como apoiadora da causa da preservação ambiental, em prol de uma face do discurso ambientalista fundamentado na homogeneização e na intolerância de sistemas culturais distintos dos da sociedade ocidental capitalista.

Interpretações de parte da sociedade joinvilense, por vezes, resultam em atos de intolerância. Uma situação específica pode ser observada em um ilê axé, situado no Bairro Adhemar Garcia, na Zona Sul de Joinville. Esta ocorrência ganhou contornos mais graves, pois a invasão do espaço pela polícia militar se deu em plena função ritual, motivada por denúncias de maus tratos aos animais e de possíveis sacrifícios de crianças. Aqui vale destacar a reportagem de capa do caderno AN cidade do jornal A Notícia, que circula no município de Joinville e região, com foto colorida, apresentando carcaças de animais atadas a um pequeno arbusto e a policia militar ambiental ao fundo observando a cena. Abaixo da foto a legenda, em letras garrafais negritadas, "MAUS TRATOS", seguida de "policiais militares e ambientais flagram animais mortos, ossos e peles em terreiro de Candomblé e responsabilizam proprietário por crime ambiental".

${ }^{20}$ SAAVEDRA, Jefferson. Joinville de Zarcão, Jornal A Notícia, Joinville, Santa Catarina, 11 de abril de 2008, p. 3. (jornal impresso). 
A reportagem completa foi apresentada na parte policial do caderno e foi intitulada de "Crime Ambiental flagrado em terreiro de Candomblé". ${ }^{21}$ Nela o repórter, numa descrição própria de matérias de cunho policial, narra o evento ocorrido. A reportagem afirma que o proprietário do terreiro foi acusado por maus tratos contra os animais e pela presença de crianças no ritual. As ações da Polícia Militar, seguida da Polícia Ambiental e Conselho Tutelar, foram motivados por denuncias de membros da própria comunidade para os quais, segundo a reportagem "a instalação do terreiro representa um problema. Eles reclamam do barulho dos tambores durante a noite e se dizem assustados com a presença de crianças na residência". Para reforçar o jornalista usa a fala de uma moradora, identificada como Norma Kist, de 56 anos e vice-presidente da associação de moradores do loteamento Nova Joinville, a qual afirma: "Ninguém mais consegue ter sossego aqui, sem falar nessa matança de animais". ${ }^{22}$

A reportagem informa, ainda, que o responsável pelo terreiro foi encaminhado ao $5^{\circ} \mathrm{DP}$ onde passou a responder a um Termo Circunstanciado por crueldade contra os animais, destacando que a pena prevista no artigo 32 da Lei 9.605 de 1998 é a detenção de três meses a um ano, mais multa, podendo ser aumentada se ocorrer a morte do animal. ${ }^{23}$

${ }^{21}$ VARGAS, Diogo. Crime Ambiental flagrado em terreiro de candomblé, Jornal A Notícia. Disponível em: http://an.uol.com.br/ancidade/2004/dez/08/3pol.htm. Acesso em 28 março 2006. (Com a venda do Jornal ao Grupo RBS, muitas notícias foram tiradas no ar. Portanto, a esta notícia não é mais possível ter acesso via on-line.) As notas referentes a este autor são citadas também a partir da minha tese de doutorado. MACHADO, Gerson. Os Atabaques da Manchester: subjetividades, trajetórias e identidades religiosas afro-brasileiras em Joinville/S (1980-200) Itajaí: Casa Aberta, 2014.

${ }^{22}$ VARGAS, 2004. Acesso em 28 mar. 2006. (O texto não se encontra mais on-line, conforme acima mencionado).

${ }^{23}$ PRESIDÊNCIA DA REPÚBLICA CASA CIVIL SUBCHEFIA PARA ASSUNTOS JURÍDICOS. Lei institui o Sistema Nacional de Unidades de Conservação da Natureza-SNUC. De acordo com: Art. 32. Praticar ato de abuso, maus-tratos, ferir ou mutilar animais silvestres, domésticos ou domesticados, nativos ou exóticos:

Pena - detenção, de três meses a um ano, e multa.

$\S 1^{\circ}$ Incorre nas mesmas penas quem realiza experiência dolorosa ou cruel em animal vivo, ainda que para fins didáticos ou científicos, quando existirem recursos alternativos.

$\S 2^{\circ}$ A pena é aumentada de um sexto a um terço, se ocorre morte do animal. Disponível em: https://www.planalto.gov.br/ccivil_03/leis/19605.htm, Acesso em 23.10.2015. 
Outro aspecto destacado pela reportagem foi a descrição do local onde o fato ocorreu

(...) em frente à residência, ontem de manhã, havia alguns sacos plásticos tomados por moscas. Mas o que mais chamava a atenção estava pendurado nas árvores: pombas e passarinhos mortos, além de ossos, que seriam de carneiros. Numa parede de concreto, dois couros de bode estavam expostos. ${ }^{24}$

Para completar o quadro o jornal publica, no respectivo caderno, uma charge sobre a situação, num tom de deboche em relação aos atingidos mais diretamente pela intervenção policial, reforçando, infelizmente, o caráter policialesco e sensacionalista que o evento acabou adquirindo nas páginas impressas desse veículo de comunicação (Figura1).

\section{Figura 01 - Charge publicada no Jornal A Notícia - reforço do suposto crime ambiental em terreiro}

\section{charge}

ANIMAS MORTOS ProvocAM

INTERDICÁD DE TERRETRO DE MAOIMBA

PELA POĹCIA AMBIENTAC

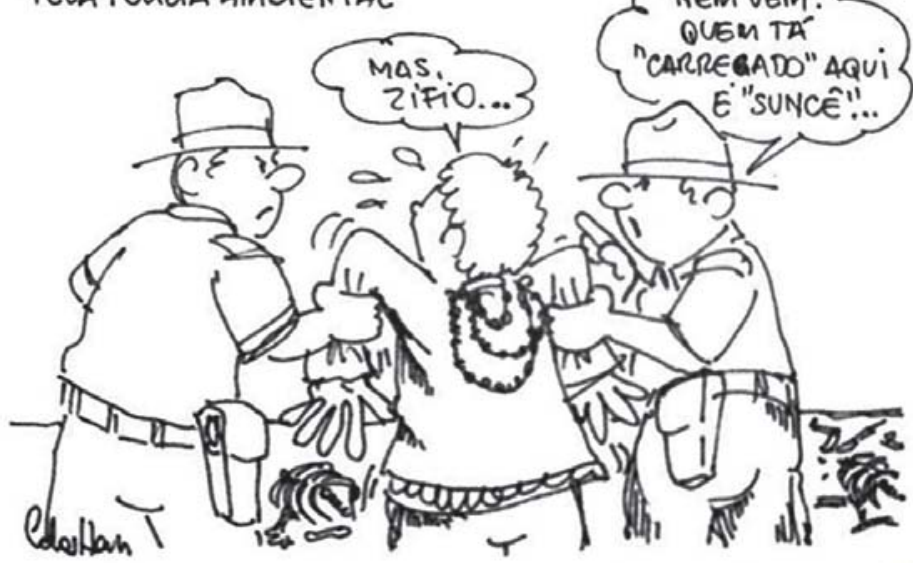

Fonte: Jornal A Notícia, - 08.12.2004.

\footnotetext{
${ }^{24}$ VARGAS, 2004. Acesso em 28 de março 2006.
} 
Ainda, na charge, produzida por Carlos Horn, o título em letras maiúsculas anunciava: "Animais Mortos Provocam Interdição de Terreiro de Macumba Pela Polícia Ambiental". No desenho dois policiais seguravam pelo braço um homem, com colares pendurados no pescoço e que pronunciava: "Mas Zifio...". Enquanto o policial postado à direita intercala: "Nem vem! Quem tá "carregado" aqui é "suncê"!...". Ao fundo esqueletos de animais jogados no chão, sem qualquer critério.

Esses estranhamentos expressos na reportagem e na charge revelam, pelo menos, três situações: a primeira é a conjugação, num mesmo espaço, de funções residenciais e de culto, a segunda, o fato da cidade ainda não estar acostumada com manifestações dessa natureza. É costumeiro que nos ilês axés ocorra a exposição de determinadas partes dos animais sacralizados ${ }^{25}$ nos rituais servindo como forma de ostentar e comprovar que determinados rituais veiculadores de axé, através do ejè (sangue) de animais, foram cumpridos conforme determina os rituais. Assim, o couro de cabritos, penas de aves, entre outros elementos, são indicadores de que tais rituais foram executados com precisão e fartura, e ficam expostos nos umbrais e paredes dos templos religiosos. Vale ressaltar que o restante dos animais sacralizados são consumidos pelos membros do $e g b e^{26}$, durante o longo período em que ficam dedicados às funções rituais, nas festas públicas e o excedente é distribuído a todos os que necessitam.

Todavia, preciso problematizar um pouco mais essa questão, pois, se de um lado parte da cidade não possui os elementos necessários para o exercício da tolerância, os oficiantes da religião afro-brasileira em questão, não tiveram a sensibilidade de perceber o quanto a exposição de rituais como esses que, tradicionalmente, são feitos distantes dos olhos dos não iniciados, redundaram em ações de violências como a que estamos trazendo à análise e discussão.

Esses vetores me encaminham para um terceiro ponto de reflexão, o qual se inspira nas contribuições de Sir Keith Thomas que explica como se deu a ascensão de uma nova sensibilidade no homem moderno,

\footnotetext{
${ }^{25}$ Optei pelo uso do termo sacralização (sacralizado, sacralizar) a fim de respeitar o significado atribuído a este ato pelos membros das comunidades de culto aos orixás.

${ }^{26}$ Termo yorubano que se aproxima da concepção de comunidade tradicional.
} 
em relação aos seres de outras espécies, essenciais à manutenção da sociedade humana, ou seja:

por um lado, eles viram um aumento incalculável do conforto, bem-estar e felicidade materiais dos seres humanos; por outro lado, davam-se conta de uma impiedosa exploração de outras formas de vida animada. Havia, dessa maneira, um conflito crescente entre as novas sensibilidades e os fundamentos materiais da sociedade humana. ${ }^{27}$

Sobretudo, ficou cada vez mais evidente que "o abismo entre as necessidades humanas, por um lado, e as sensibilidades do mesmo homem, por outro, se ampliara muito" ${ }^{28}$. Thomas alerta que tal conflito está longe de ser resolvido e afirma que "é possível ser essa uma das contradições sobre as quais se assenta a civilização moderna." 29

Embora considerando as devidas diferenças entre o caso da ascensão dessa nova sensibilidade em solo britânico, no período compreendido entre os séculos XVI e XIX, e o presente caso joinvilense, temos de certa forma, o mesmo conflito de sensibilidades distintas, entre diferentes grupos da sociedade. Se, de um lado, temos um grupo cujo emprego do sacrifício de animais para fins rituais e alimentares é um dado corrente para sua performance; de outro, temos um grupo munido dessa nova sensibilidade e dos valores adquiridos no trânsito pelo universo cosmológico e doutrinário judaico-cristão, que com o passar do tempo se desvinculou do processo de obtenção de fontes de proteína animal.

Tal desvinculação é diretamente informada pela Bíblia a qual reforça continuamente os ensinamentos do livro do Êxodo. Neste, Moisés, ao retornar da montanha sagrada, condena veementemente a prática de sacrifício animal aos outros deuses: "O Senhor disse a Moisés: "Vai, desce! Porque se corrompeu o teu povo que tiraste do Egito. Desviaram-se depressa do caminho que lhes prescrevi; fizeram para si um bezerro de metal fundido, prostraram-se diante dele e ofereceram-lhe sacrifícios." 30

\footnotetext{
27 THOMAS, Keith. O Homem e o Mundo Natural: mudanças de atitude em relação às plantas e aos animais (1500-1800). São Paulo: Companhia de Letras, 1996, p. 358.

28 THOMAS, 1996, p. 228.

29 THOMAS, 1996, p. 358.

30 Texto bíblico do Êxodo 32,7-8 (Bíblia Ave Maria)
} 
Essas admoestações são muito eficazes no sentido de mobilizar a opinião e as atitudes dos que professam tal religião, impelindo-os ao combate sistemático aos demais.

É importante esclarecer que o terreiro funcionava na casa do acusado, uma modesta residência com área construída de, no máximo, $200 \mathrm{~m}^{2}$, incluindo o barracão, onde ocorriam as cerimônias públicas. O imóvel está cercado por uma numerosa vizinhança, separado apenas por um muro de concreto e tijolos, que não permite muita privacidade aos seus moradores. Vale lembrar que o Candomblé é uma religião que desenvolve boa parte dos seus rituais de forma secreta, especialmente a sacralização dos animais. É um ritual muito significativo, pois é principalmente através dele que o axé é veiculado ao elegùn $n^{31}$ e nos materiais destinados ao culto. ${ }^{32}$

Nesse sentido, o espaço em questão não oferecia condições para a prática ao culto tradicional aos orixás, revelando uma adaptação do culto às condições estruturais oferecidas pelo espaço urbano. Esse fenômeno já foi observado em outros lugares, especialmente na cidade de São Paulo, onde a disponibilidade de espaço é muito menor do que em Joinville. ${ }^{33}$

Observa-se, portanto, que o culto aos orixás em Joinville, pelo menos nesse caso, seguiu um critério pragmático, fugindo ao modelo mais tradicional, em que há uma necessidade de um espaço muito amplo, com capacidade para a construção de casas individualizadas, destinadas ao culto a orixás particulares e um espaço coletivo denominado barracão, onde ocorrem as cerimônias coletivas e públicas, além da mata/floresta, onde determinados cultos devem ocorrer. Essa organização ideal representa a configuração de algumas aldeias yorubanas africanas, em que haviam lugares destinados à privacidade, à coletividade e ao segredo. ${ }^{34}$

Diante da situação descrita resolvi retomar a questão, tempos depois do fato noticiado, e entrevistei os principais personagens, o Babalaorixá M. de Oxóssi e a sua esposa C. de Iyemanjá. O caso assumiu um contorno

\footnotetext{
31 Termo yorubano que designa o iniciado para um determinado orixá.

32 Para um detalhamento maior do axé e das formas de veiculação do mesmo conferir: SANTOS, Juana Elbein dos. Os Nagô e a morte. 9. ed. Petrópolis: Vozes, 1986, p. 46-52.

${ }^{33}$ SILVA, Vagner Gonçalves da. Orixás da metrópole. Petrópolis: Vozes, 1995. O autor discute como o culto aos orixás se estabelece em São Paulo, num cenário de competição e ressignificação do espaço urbano, em função da cosmologia yorubana.

${ }^{34}$ SANTOS, 1995, p 75.
} 
mais traumático, pois, no momento da invasão do ilê axé, o Sr. M. de Oxóssi estava recolhido no runk $o^{35}$ do santo, tomando a sua obrigação de sete anos, a qual completa o ciclo iniciático e dá autonomia ao iniciado para, se for o seu destino, encabeçar um ilê axé, exercendo a sua autoridade sobre uma determinada comunidade conforme a tradição.

O runkó é um dos espaços mais sagrados de um ilê axé. É nele que ocorrem os rituais mais secretos. Simbolicamente representa um útero fecundado, de onde será "parido" o orixá devidamente cultuado. Nesse sentido, acredita-se que ele seja um local puro e imaculado, que não pode ser contaminado com as coisas do mundo profano. Entretanto, o Sr. Marcos foi abruptamente arrancado do seu recolhimento para a delegacia, onde foi prestar depoimentos. Esse acontecimento teve um significado nefasto tanto para a vida civil quanto para a vida religiosa do entrevistado. Dessa forma o ciclo de violência que se apresentou atingiu não somente essa comunidade mas serviu para mobilizar o coletivo do povode-santo da cidade, até então, desarticulado. O rescaldo de tal acontecimento serviu para coagular o grupo na luta por mais respeito, dignidade e pela cobrança junto às autoridades de ações de políticas públicas voltadas ao respeito, ao reconhecimento e à afirmação da cultura e identidade afro-brasileira na cidade.

Assim, não contentes com essa situação lideranças de diversas casas de religião de matriz afro-brasileira de Joinville reuniram-se, no auditório do Museu Arqueológico de Sambaqui de Joinville, no dia 26 de março de 2005, para debater essa e outras situações que atingiam os direitos de livre exercício de culto, preconizado no artigo $5^{\circ}$ da Constituição da República Federativa do Brasil, de $1988^{36}$. Como resultado de

\footnotetext{
${ }^{35}$ Runkò, é um espaço aonde o neófito e/ou a pessoa que venha dar as obrigações de santo ficam recolhidos, afastados da vida mundana. Alimentação e banhos especiais, entre outros cuidados, cercam a pessoa que fica recolhida.

${ }^{36}$ CONSTITUIÇÃO DA REPÚBLICA FEDERATIVA DO BRASIL. Art. $5^{\circ}$ Todos são iguais perante a lei, sem distinção de qualquer natureza, garantindo-se aos brasileiros e aos estrangeiros residentes no País a inviolabilidade do direito à vida, à liberdade, à igualdade, à segurança e à propriedade, nos termos seguintes:

(...)

VI - é inviolável a liberdade de consciência e de crença, sendo assegurado o livre exercício dos cultos religiosos e garantida, na forma da lei, a proteção aos locais de culto e a suas liturgias;
} 
intensas discussões foi produzido um manifesto público que expressou os direitos, os papéis sociais e as reivindicações do grupo. $\mathrm{O}$ evento teve repercussão na imprensa local, com abordagens tanto em emissoras de televisão quanto em jornal impresso. ${ }^{37}$

Esse documento foi entregue à imprensa e autoridades, em diversas oportunidades. Inclusive, no ano de 2010, outro manifesto baseado naquele produzido em 2005, foi apresentado na Câmara de Vereadores de Joinville, durante evento da $2^{a}$ Semana da Consciência Negra, ocorrido em novembro de 2010, o qual reivindicou:

O livre acesso aos cemitérios públicos no período noturno,

A garantia de segurança durante a realização dos rituais em cachoeiras, vias públicas (encruzilhadas), praias, matas e manguezais.

Manifestamos um desejo, inclusive, de termos uma espécie de "recanto" destinado ao culto aos orixás em áreas de preservação ambiental, (...)

Seja elaborado um programa de educação ambiental voltada ao povo-de-santo. ${ }^{38}$

É valido ressaltar que, o caso do ilê axé invadido pela Polícia Ambiental serviu para a constituição de um movimento coletivo articulado não por uma associação ou federação, mas sim em rede, de maneira mais rizomática. Portanto, a invasão trouxe como reação a organização e constituição de um movimento articulado, coletivo, em rede, tornando assim público o direito de ser da religião afro em Joinville, de acordo com o Manifesto Público do Povo do Santo.

VII - é assegurada, nos termos da lei, a prestação de assistência religiosa nas entidades civis e militares de internação coletiva;

VIII - ninguém será privado de direitos por motivo de crença religiosa ou de convicção filosófica ou política, salvo se as invocar para eximir-se de obrigação legal a todos imposta e recusar-se a cumprir prestação alternativa, fixada em lei (...).

Disponível em: http://www.planalto.gov.br/ccivil_03/Constituicao/Constituicao. htm. Acesso em 10 de novembro de 2015.

${ }^{37}$ BINDEMAN, Micheli. Religiões afro-brasileiras buscam espaço em Joinville, Jornal A Notícia, Joinville: 02 de Abr. 2005. (NA Cidade - Geral) (impresso).

${ }^{38}$ MANIFESTO PÚBLICO DO POVO DE SANTO DE JOINVILLE. Manifesto. Joinville: panfleto, 20 de novembro de 2010. 


\section{Concluindo}

Se a instalação de terreiros em casas comuns pode provocar atitudes de estranhamento por parte da comunidade, é de se supor que pode ocorrer um desvelamento e uma aproximação maior dessas práticas com a cidade. A falta de privacidade no espaço urbano, que se configura como um espaço vazado, no qual tudo passa, paradoxalmente, a ser visível e invisível, tem provocado um interessante movimento, contemporâneo de afirmação da identidade religiosa afro-brasileira, com processos que passam, inclusive pela apropriação e ressignificação de espaços públicos, que até então, enalteciam a herança colonial europeia. ${ }^{39}$ De acordo com Pinheiro e Folmann:

No Brasil, por muito tempo, tentou-se resolver o futuro das relações étnico-raciais através do esquecimento. Hoje, finalmente, com muita lucidez, vivemos políticas que colocam em primeiro plano a memória. Não se trata da memória oficial, mas da memória que, por muito tempo, foi cultivada e conseguiu sobreviver nos subterrâneos da nossa história. ${ }^{40}$

O respeito à diversidade religiosa e cultural necessita fazer parte dos processos educativos seja na escola, nas universidades e outros espaços formativos e educativos. No entanto, o direito à diversidade também necessita ser garantido pelos poderes públicos como parte integrante dos direitos humanos e da constituição brasileira. As memórias subterrâneas são elementos fundantes na defesa de novas propostas e de reconstrução das religiões afro-brasileiras nas cidades.

${ }^{39}$ MACHADO, Gerson. Os atabaques da Manchester: subjetividades, trajetórias e identidades religiosas afro-brasileiras em Joinville/SC (1980-2000). Itajaí/SC: Editora Casa Aberta, 2014, p. 262-278.

${ }^{40}$ PINHEIRO, Adevanir Aparecida; FOLMANN, José Ivo. Negros e brancos no Brasil: três pontos de reflexão. Identidade!, v.16, n.2, 2011. Disponível em: http:// www.est. edu.br/periódicos/index. php/ identidade. Acesso em 16.10.2015, p. 1. 


\section{Referências}

BINDEMAN, Micheli. Religiões afro-brasileiras buscam espaço em Joinville, Jornal A Notícia, Joinville: 02 de Abr. 2005. (NA Cidade Geral) (impresso).

CONSTITUIÇÃO DA REPÚBLICA FEDERATIVA DO BRASIL. Disponível em: http://www.planalto.gov.br/ccivil_03/Constituicao/Constituicao.htm. Acesso em 10 de novembro de 2015.

Evangélicos tentam invadir terreiro em Olinda. Disponível em: http://jconline.ne10.uol.com.br/canal/cidades/noticia/2012/07/18/ evangelicos-tentam-invadir-terreiro-em-olinda-49482.php. Acesso em 12.11.2015.

JUNGES, Leandro S. Pai de santo é agredido com pedradas em Araquari, Norte de Santa Catarina. Disponível em: http://anoticia.clicrbs.com.br/sc/geral/noticia/2015/10/pai-de-santo-e-agredido-compedradas-em-araquari-norte-de-santa-catarina-4875162.html. Acesso em 12.11.2015.

MACHADO, Gerson. Os atabaques da Manchester: subjetividades, trajetórias e identidades religiosas afro-brasileiras em Joinville/SC (1980-2000). Itajaí/SC: Editora Casa Aberta, 2014.

MANIFESTO PÚBLICO DO POVO DE SANTO DE JOINVILLE. Manifesto. Joinville: panfleto, 20 de novembro de 2010.

MAZZI, Carolina, RJ: Aluno é impedido de frequentar escola com guias de candomblé. Disponível em: http://educacao.uol.com.br/ noticias/2014/09/03/rj-aluno-e-impedido-de-frequentar-escola-comguias-de-candomble.htm - Acesso em 12.11.2015.

PINHEIRO, Adevanir Aparecida; FOLMANN, José Ivo. Negros e brancos no Brasil: três pontos de reflexão. Identidade!, v.16, n.2, 2011. Disponível em: http:// www.est.edu.br/periódicos/index. php/ identidade. Acesso em 16.10.2015.

REIS, João José; SILVA, Eduardo. Negociação e conflito. São Paulo: Companhia das Letras, 1989.

PRESIDÊNCIA DA REPÚBLICA CASA CIVIL SUBCHEFIA PARA ASSUNTOS JURÍDICOS. Lei institui o Sistema Nacional de Unidades de Conservação da Natureza-SNUC. Disponível em: https://www. planalto.gov.br/ccivil_03/leis/19605.htm, Acesso em 23.10.2015. 
SAAVEDRA, Jefferson. Joinville de Zarcão, Jornal ANotícia, 11.04.2008, Joinville, Santa Catarina, p. 3. (jornal impresso).

SANTOS, Juana Elbein dos. Os Nagô e a morte. 9.ed. Petrópolis: Vozes, 1986.

SILVA, Vagner Gonçalves da. Orixás da metrópole. Petrópolis: Vozes, 1995. VARGAS, Diogo. Crime Ambiental flagrado em terreiro de candomblé, Jornal A Notícia. Disponível em: http://an.uol.com.br/ancidade/2004/ dez/08/3pol.htm. Acesso em 28 março de 2006. (O texto não se encontra mais on-line).

Submetido em: 30/11/2015

Aceito em: 12/04/2016 